Cahiers $d u$ MONDE RUSSE

\section{Cahiers du monde russe}

Russie - Empire russe - Union soviétique et États indépendants

$57 / 4 \mid 2016$

Varia

\title{
Aristocratic Subjectivity in Revolutionary Turmoil
}

I.I. Bariatinskii's “Coup d'œil sur Genève” (1791)

Subjectivité aristocratique dans la tourmente révolutionnaire : le "Coup d'œil sur Genève » du prince I.I. Barjatinskij

\section{Andreas Schönle}

\section{OpenEdition}

\section{Journals}

Electronic version

URL: http://journals.openedition.org/monderusse/9985

DOI: $10.4000 /$ monderusse. 9985

ISSN: $1777-5388$

Publisher

Éditions de l'EHESS

\section{Printed version}

Date of publication: 1 October 2016

Number of pages: $711-742$

ISBN: 978-2-7132-2542-0

ISSN: $1252-6576$

\section{Electronic reference}

Andreas Schönle, «Aristocratic Subjectivity in Revolutionary Turmoil », Cahiers du monde russe [Online], 57/4 | 2016, Online since 01 October 2018, Connection on 04 January 2020. URL : http:// journals.openedition.org/monderusse/9985; DOI : 10.4000/monderusse.9985 


\section{ARISTOCRATIC SUBJECTIVITY IN REVOLUTIONARY TURMOIL}

\section{I.I. Bariatinskii’s “Coup d'œil sur Genève” (1791)}

This essay will revisit a vexed question in Russian historiography, the extent of the immediate influence on Russia's best minds of revolutionary events in France and elsewhere in the early $1790 \mathrm{~s} .{ }^{1}$ Political and diplomatic history aside, the impact of the Revolution on Russia's intellectual history has been contentious. In Soviet times, the "Great French Revolution" was seen as an antecedent to the Bolshevik revolution, which encouraged the "discovery" of elective affinities between Russians and the Revolution. ${ }^{2}$ In this general context, one way to rehabilitate a writer or thinker in the watchful eyes of ideological gatekeepers was to demonstrate his (or, more rarely, her) support for the French Revolution, or more broadly and vaguely, their revolutionary convictions. Aleksandr Radishchev, of course, was fair game, along with the minor authors he influenced. ${ }^{3}$ But so was Nikolai Karamzin, whom Iurii

1. Research for this article was made possible by a grant from The Leverhulme Trust (RPG-357), whose support is gratefully acknowledged. This essay also owes much to the suggestions of several anonymous reviewers, who generously shared their erudition with me.

2. The standard Soviet account of Russia's response to the French Revolution is M.M. Shtrange, Russkoe obshchestvo i frantsuzskaia revoliutsiia 1789-1794 gg. [Russian society and the French revolution 1798-1794] (M.: Izdatel'stvo ANSSSR, 1956). Shtrange refers to the "Russian intelligentsia's" unanimous embrace of the Revolution, a social group that didn't yet exist in Russia (65). See also, in the same vein, K.E. Dzhedzhula, Rossiia $i$ velikaia frantsuzskaia burzhuaznaia revoliutsiia kontsa XVIII veka [Russia and the great French bourgeois revolution of the end of the eighteenth century] (Kiev: Izdatel'stvo Kievskogo universiteta, 1972).

3. See G.A. Gukovsii, Russkaia literatura XVIII veka [Russian literature of the eighteenth century] (1939; M.: Aspekt Press, 1998), 388-391. Iu.M. Lotman gave a more differentiated account of Radishchev's views on the Revolution, emphasising his uncompromising defence of individual human rights and his ensuing critique of the Jacobine terror and the Directory. See Iu.M. Lotman, "Politicheskoe myshlenie Radishcheva i Karamzina i opyt frantsuzskoi revoliutsii [The political thought of Radishchev and Karamzin and the experience of the French revolution]," in Iu.M. Lotman, Karamzin (SPb.: Iskusstvo-SPB, 1997), 601-605. 
Lotman called, not without evidence, a supporter of the early stages of the Revolution and even a secret admirer of Robespierre, a manifestation of his preference for state-directed utopia. ${ }^{4}$ More recently, the intellectual influence of the revolutionary upheavals has been played down. Vladislav Rjéoutski and Aleksandr Chudinov boldly contend that in the absence of any comparable revolutionary movements in Russia and the limited impact of the publication of Radishchev's Journey from Petersburg to Moscow, one must conclude that the Revolution did little to sway the minds of Russians, with the exception of a few early sympathisers. In particular, Rjéoutski and Chudinov offer a revisionist analysis of the alleged participation of young Russian aristocrats in the unfolding of revolutionary events in Paris, notably that of Pavel Stroganov and the brothers Boris and Dmitrii Golitsyn in 1789-1790.5 While they correctly point out that the actions of these scions of the elite do not add up to "participation" in the Revolution properly speaking, they leave aside the question of the Revolution's moral repercussions. To complement their analysis, this article will thus move from the level of social action to that of moral selffashioning and attempt to trace the impact of the Revolution on the subjective self of a member of the elite.

To this effect, I will consider the writings of Prince Ivan Ivanovich Bariatinskii (1772-1825), who may have witnessed a short period of the Revolution in Paris in 1790 , before traveling to study in Geneva and becoming an observer of the street unrest and revolutionary fervour in the cité de Calvin. Bariatinskii kept a notebook in the years 1790-92, to which he confided his thoughts and observations, as well as writing a short, more formal text on the political situation in Geneva entitled "Coup d'œil sur Genève." These archival texts will allow me to trace how the subjective identity of a member of the elite was affected by the spectacle of the unfolding Revolution and to assess the extent to which his subsequent life was informed by this experience. The account I shall present here does not, of course, invalidate the conclusions of a more "macro-historical" analysis, but it shows that the French Revolution caused aristocrats to question their role in society, evaluate the extent of their freedoms, and think about how they could lead a meaningful existence in an autocratic society without losing their moral integrity. Indeed, I will briefly discuss the fact that Pavel Stroganov was among those marked by the Revolution in this way. The fact that these reflective questions, this political and moral soul-searching, arose among a group of elite members of society can be seen as one of the indirect effects of the French Revolution in Russia. Due to its intrinsic interest, an annotated

4. See Lotman, "Politicheskoe myshlenie Radishcheva i Karamzina," 605-613 and Iu.M. Lotman and B.A. Uspenskii, "'Pis'ma russkogo puteshestvennika' Karamzina i ikh mesto v razvitii russkoi kul'tury [Karamzin's Letters of a Russian Traveller and their place in the development of Russian culture]," in N.M. Karamzin, Pis'ma russkogo puteshestvennika [Letters of a Russian Traveller] (L.: Nauka, 1984), 550.

5. V.S. Rzheutskii, A.V. Chudinov, "Russkie 'uchastniki' frantsuzskoi revoliutsii [The Russian 'participants' in the French revolution]," Frantsuzskii ezhegodnik, 2010 (M : Kvardiga, 2010), $6-45$. 
version of Bariatinskii's "Coup d'œil sur Genève" will be published in an appendix to this article.

Born in 1772, Ivan Ivanovich Bariatinskii belonged to the upper echelon of the Russian elite and received a Europeanized education characteristic of young men of his social standing. His mother, Princess Ekaterina von Holstein-Beck, descended from the ducal family of Schleswig-Holstein-Sonderburg-Beck, her father having been the governor of Estonia. Bariatinskii's father, Prince Ivan Sergeevich Bariatinskii, the descendant of a Chernigov princely family, was Russian ambassador at the court of Louis XVI between 1774 and 1786. His parents became estranged due to their respective infidelities, and after her return from Paris in 1776, his mother led the high life in St. Petersburg, entertaining lavishly in her stately mansion on Millionnaia Street. Ivan Ivanovich grew up in this atmosphere and was actively engaged in home theatre, which his mother supported by recruiting young nobles with theatrical talent to perform plays together with her children. ${ }^{6}$ Yet in letters written prior to the end of 1788, at age sixteen or less, Bariatinskii referred with much sympathy to Rousseau, in particular to the Rêveries du promeneur solitaire, in which he allegedly absorbed himself repeatedly. As he wrote to an unknown correspondent, "je ne connais pas de lecture qui soit plus convenable à mon caractère, qui m'émeuve et me remue autant l'âme, et qui me fasse plus entrer dans la triste et pénible situation de l'auteur."7 The reading practice in evidence here involves sympathetic identification with the author, a sentimental posture intensified by recurrent reading of one and the same text, which stimulates introspective emotional engagement with the text. From Rousseau, Bariatinskii also learned the appreciation of nature, which he contemplated through the eyes of the author: "En admirant des choses que lui même a tant admiré, je m'élève jusqu'à lui pour ainsi dire," he wrote, implying that reading was a way to model oneself after the author. ${ }^{8}$ Most importantly, Bariatinskii adopted from Rousseau the notion that reading fosters the cultivation of interiority and of self-reflection, that it stimulates the work of memory, sharpens emotions, empowers the imagination, and channels the pursuit of the moral good.

Yet in addition to this standard sentimentalist or preromantic fare, Bariatinskii's education also emphasized historical knowledge and comparative political analysis. The same collection of letters from 1788 also features an extended essay, written or copied by him, on the subject of whether the government of the Romans can be deemed democratic, which also includes digressions into Egyptian, Babylonian, and Chinese history. In a letter of 1789, Bariatinskii seems to endorse

6. For the importance of theatre in the St. Petersburg lifestyle of the Bariatinskii children, see I.M. Dolgorukov, Kapishche moego serdtsa [The shrine of my heart] (M.: Nauka, 1997), 55.

7. "Kopii pisem, razlichnye vypiski i zametki I.I. Bariatinskogo [Copies of letters, various quotations and observations by I.I. Bariatinskii]," RGB OR (Rossiiskaia gosudarstvennaia biblioteka. Otdel rukopisei - Manuscript Department of the State Russian Library), f. 19/V, d. $117,1.2 \mathrm{ob}$.

8. Ibid, 1. 2 . 
the legitimacy of unrest in France (albeit without calling it a revolution), while at the same time expressing solidarity with the rule of Catherine the Great:

Tout semble favoriser l'heureux règne de notre grande impératrice. La Suède est en trouble et la Pologne aussi. La France est embrasée d'un bout à l'autre du feu d'une guerre intestine. Mais pour cette fois ci l'armée du juste prévaut. Le tiers État triomphe par sa fermeté et sa sagesse, et par les droits qu'il fait valoir avec autant de justice que de force. En effet pourquoi faut-il qu'une classe d'hommes si utiles à l'État supporte plus de charges que les grands qui ont pour eux tous les honneurs, tous les emplois et toutes les distinctions?"

In keeping with his interest in political economy, Bariatinskii stresses fiscal inequity as the main cause of the Revolution.

Bariatinskii left Russia in July 1789 with his mother, who sold her house in St. Petersburg and embarked on a European journey, ostensibly to seek a cure for her rheumatism. ${ }^{10}$ While she continued her tour, he stayed in Leipzig to study with Professor Ernst Platner, then a prominent, eclectic, and wide-ranging scholar who taught medicine, as well as anthropology, metaphysics, and aesthetics. ${ }^{11}$ A thick notebook entitled "L'année 1791. Écrits du Prince Ivan Ivanowitch Bariatinsky" contains a twenty-page inset named "Droit naturel. Système de Mr Platner," which appears to represent his lecture notes. ${ }^{12}$ In autumn 1790, Bariatinskii travelled to

\section{Ibid, 1. 47 .}

10. Her journal shows her crisscrossing Europe, being as interested in the arts and society as in health spas. See "Bariatinskaia Ekaterina Petrovna, ur. Golshtein-Bek, Zapiski o puteshestvii po Evrope [Ekaterina Petrovna Bariatinskaia, née Golstein-Beck, Notes of a journey through Europe]," RGB OR, f. 19, op. 5/2, d. 12. Some excerpts, along with a helpful discussion of francophone diaries written by women of the time, can be found in Elena Gretchanaia and Catherine Viollet, eds., "Si tu lis jamais ce journal...": Diaristes russes francophones 1780-1854 (P.: CNRS Éditions, 2008).

11. Platner is known primarily as the founder of interdisciplinary anthropology, understood as an attempt to think through the connections between body and soul and overcome Descartes's dualism. He was a charismatic teacher, well known among foreign travellers, including Russians. Radishchev had attended his lectures in 1770-1771 and Karamzin wrote a rapturous account of a lecture he attended in July 1789, a few weeks before Bariatinskii's arrival: Karamzin, Pis'ma russkogo puteshestvennika, 63-64. See Alexander Koshenina, Ernst Platners Anthropologie und Philosophie (Würzburg: Verlag Dr. Johannes Königshausen, 1989), 17; Helmut Grasshoff, "Nachwort" in A.N. Radistschew, Reise von Petersburg nach Moskau (Berlin: Rütten \& Loening, 1961), 253-256. Although his public consisted primarily of the nobility, according to one of his students, he cast aspersions on the first estate, drawing "satirical pictures of estate prejudices, the pride of nobility and money, distinguished stupidity, and the compulsion of the privileged classes to oppress" (quoted in Koshenina, 13).

12. "Chernoviki, zapiski, zametki, rassuzhdeniia I.I. Bariatinskogo [Drafts, notes, observations and reflexions of I.I. Bariatinskii]," RGB OR, f. 19, op. 2, papka 253, d. 1, 1. 13-33. References to this notebook, which represents the core evidence for Bariatinskii's intellectual development in his student years, will henceforth be given directly in parentheses. Platner's contributions to legal theory have received little attention, except for a brief mention that he aimed to defend natural law theory against Kant's critique of it. See Simone De Angelis, "Unbewusste Perzeptivität und metaphysisches Bedürfnis: Ernst Platners Auseinandersetzung mit Haller in den Quaestiones physiologicae (1794)," Aufklärung, 19 (2007): 243-273, here 245-246. In his Philosophical Aphorisms, Platner devoted several paragraphs to a critique of the Hobbesian state of nature, though without addressing theories of sovereignty and the social contract (Ernst 
Geneva, where he was to continue his studies. However, his notebook entry for 17 November 1790 refers to a speech at the National Assembly, of which I could not find any account in the relevant press, and to the conflicting public perception of Mirabeau (3). It is thus possible that Bariatinskii stopped in Paris on his way to Geneva. Another reason to come to Paris would have been to make the acquaintance of his half-sister, Appuline Anne Jeanne Philippe, dite de Saint Pray, the illegitimate daughter of his father, born in $1783 .{ }^{13} \mathrm{He}$ stayed in touch with her and visited her several times during his subsequent European travels, while she sent him regular reports about literary and artistic life in Paris.${ }^{14}$ His presence in Paris during the French Revolution would be anything but inconsequential, as on 4 June 1790, the Russian emissary I.M. Simolin had received instructions from Catherine to send all Russians home..$^{15}$ There is no evidence that Simolin was aware of Bariatinskii's presence in Paris.

Bariatinskii's notebook indicates a keen interest in the unfolding of the Revolution. Bariatinskii was a supporter of Mirabeau, and we can rank him among the moderates who favoured a constitutional monarchy. He called the Revolution "le triomphe de la philosophie" and "le plus bel effort de l'esprit humain," drawing a direct line between the Enlightenment and the Revolution (9ob). In his analysis of the causes of the Revolution, he emphasized the despotic role of the nobility and the weakness of the king, contradicting absolutist political theory. In France

une indépendance générale, mais [qui] dans le fond n'était qu'une olygarchie [sic] tyrannique y fut transplantée tout d'un coup. Le Roi n'était rien et l'apparente indépendance dont jouissait la Nation n'était qu'un prétexte dont se servirent les nobles de l'enchaîner avec le trône pour se les soumettre tous les deux tour à tour (10).

Accordingly, he is surprisingly sanguine, for an aristocrat, about the necessity of destroying the nobility as a political force:

On a vu les nobles de temps immémorial coloniser la monarchie. Ils ont même élevé le Roi et cela pour leur propre terme. Aussi a-t-on eu bien soin d'anéantir le corps de la noblesse pour établir un gouvernement populaire. Sa chute a été le signal de celle du trône et ces deux corps qui étoient jadis aussi inséparables

Platner, Philosophische Aphorismen, vol. 2 (Leipzig: im Schwickertschen Verlage, 1782), par. 293-315, p. 111-126.

13. "Metricheskaia vypiska [Extract of Register]," RGB OR, f. 19, op. 2, papka 29, d. 9, 1. 1.

14. Her extensive and interesting letters are generally impersonal if not deferential, but in one of them, she reveals that she was beside herself with joy at the news of his arrival in Paris ("Mme de Saint Pray. Pis'ma k I.I. Bariatinskomu. 1812-17 [Mme de Saint Pray. Letters to I.I. Bariatinskii, 1812-1817]," RGB OR, f. 19, op. 2, papka 27, d. 1, 1. 409ob). In October 1790, Bariatinskii's father wrote to her mother, offering a regular pension and asking for the girl and her older sister to join him in St. Petersburg, but to no avail ("Copie de la lettre du Prince Iwan Bariatinsky à Mme de Saint Pray en date du 17/28 octobre 1790,” RGB OR, f. 19, op. 2, papka 29, d. 10).

15. Literaturnoe nasledstvo, 1937, vyp. 29-30, 455-456. 
que des parties le sont d'un tout, vinrent se briser contre les marches du temple de la liberté. (10ob).

On 14 October 1790 Bariatinskii's mother arrived in Geneva, where she stayed for three days on her way to Italy. In her travel account she mentioned that her son would come and study at the Geneva Academy, but he was clearly not yet in Geneva at the time of her visit to the city. ${ }^{16}$ Only the very first entries in Bariatinskii's notebook are dated, but the placement of references to Geneva in it indicates that he stayed in the cite de Calvin at least from late 1790 to October 1792, while he also made trips to Italy and to Vienna during this period..$^{17}$

Bariatinskii never enrolled in the Geneva Academy, at least not as a regular student. ${ }^{18}$ Like most Russian aristocrats on educational journeys through Europe, he probably hired individual tutors, rather than mingling with the local student body. In any case, by the late eighteenth century, partly on account of its refusal to hire professors who were not from local aristocratic families, the Geneva Academy was in decline, and much of the new science took place outside its walls, within recently constituted scientific societies, where commoners and foreign scholars worked alongside the local elite, creating an unusually dynamic scientific milieu relative to the size of the city. ${ }^{19}$ It is quite possible that it is under the influence of Geneva's lively public life, with its diverse social circles and scientific societies, that Bariatinskii drafted his plan for the development of "literary" societies in Russia in an entry dated 21 November 1790 :

Projet. Entreprendre une feuille périodique en Russie. Établir des clubs, avoir des sociétés littéraires où l'on s'assemblerait un jour fixé pour traiter différentes matières, politique, métaphysique, histoire. [...] il faut se former une bibliothèque commune de nos bibliothèques particulières. Faire des lectures publiquement de nos ouvrages et d'autres livres. Ou bien former une bibliothèque à souscription. Cette société devrait s'engager de commerce, de la population, des moyens d'amélioration à faire en Russie (3b).

In contrast to the English clubs then in existence in St. Petersburg and Moscow, which functioned more like social hubs than incubators of knowledge, ${ }^{20}$ Bariatinskii

16. RGB OR, f. 19 , op. 5/2, d. $12,1.30$.

17. His mother arrived in Rome on 12 December 1790, where Bariatinskii posed for a wellknown family portrait by Angelica Kauffmann in early 1791.

18. His name does not figure among the list of registered students. See S. Stelling-Michaud, ed., Le livre du recteur de l'Académie de Genève (1559-1878), vol. 1 (Genève: Droz, 1959).

19. Charles Borgeaud, Histoire de l'Université de Genève, vol. 1, L'Académie de Calvin, 1559-1798 (Genève: Georg et Cie, 1900), 595-597; Marco Marcacci, Histoire de 1'Université de Genève 1559-1986 (Geneva: Université de Genève, 1987), 51; and René Sigrist, L'Essor de la science moderne à Genève (Lausanne: Presses polytechniques et universitaires romandes, 2004), 51-72. Bariatinskii may nevertheless have attended some lessons at the Academy, since formal enrolment was not required to do so (Borgeaud, 600).

20. See Mikhail Velizhev, "The Moscow English Club and the Public Sphere in Early Nineteenth-century Russia," in Andreas Schönle, Andrei Zorin, and Alexei Evstratov, eds., The 
clearly had in mind primarily the propagation of Enlightenment ideas, the transplantation into Russia of the republic of letters. He even drafted bylaws for such a circle in a document entitled "Projet de cercles à établir à Moscou et à Petersbourg," which was legitimated by the following preamble:

Persuadé que les lumières ne peuvent se répandre qu'entre connaissances d'abord, qu'en rassemblant les hommes qui les possèdent, il faut tâcher d'encourager l'existence des clubs littéraires et politiques (5ob).

He seems to envision a kind of political debating club, aimed at raising political consciousness, rather than a literary salon. Yet there is little to suggest, in his description, that such a club could function as a political force, a counterweight to the ruling elites, as it did in Geneva. ${ }^{21}$

Bariatinskii's notebook reveals considerable interest in natural law theory. One of the first entries defines the fatherland as a relationship of mutual obligations enshrined in law, rather than as a feeling that arises out of the serendipitous place of birth: "c'est que j'ai des droits sur elle [la patrie, A.S.] et qu'elle en a sur moi; c'est que j'ai des devoirs à remplir envers elle et qu'elle s'en est imposé qu'elle doit remplir envers moi." (3). More specifically, this contract between the citizens and the state rests on the citizens accepting the laws of the state and paying lawful dues to it, while the state promises to protect the goods owned by the citizens and guarantees their peaceful enjoyment. The emphasis on mutual rights and duties betrays the influence of German Protestant natural law theory, which Bariatinskii acquired through Platner.

As he arrived in Geneva, Bariatinskii entered a discursive field where natural law theory had been hotly debated, and it may be useful to sketch out briefly the parameters of this long-standing debate. By 1790, Geneva was still very much under the influence of the so called "école romande de droit naturel," which played a key role in translating and disseminating German natural law theory in francophone countries. In Geneva, the main figure was Jean-Jacques Burlamaqui (1694-1748), who taught at the Geneva Academy between 1723 and 1740 and was known for his highly successful synthesis of German natural law, published in two volumes, Principes $d u$ droit naturel (1747) and Principes du droit politique (1751). The second volume was published posthumously in an unauthorized version, but nevertheless became

Europeanized Elite in Russia, 1762-1825: Public Role and Subjective Self, (DeKalb: Northern Illinois University Press, 2016), 220-237.

21. The following quotation from the future Girondist Jacques Pierre Brissot gives an example of the role political circles played in the mythology of Genevan mores: "Ces cercles politiques sont peut-être au nombre de 200 dans Genève. Je vous ai déjà parlé de leur effet. C'est la plus sûre base de la liberté, la plus sûre barrière contre l'ambition des magistrats. Ces cercles remplacent les cafés, les spectacles où l'oisiveté va se délasser, ou plutôt s'avilir et se corrompre dans les gouvernements monarchiques. Il en résulte que les Genevois ont des mœurs plus saines, et l'esprit plus éclairé." Le Philadelphien à Genève, Lettres d'un Américain sur la dernière révolution de Genève, sa Constitution nouvelle, l'émigration en Irlande, etc. pouvant servir de tableau politique de Genève jusqu'en 1784 (Dublin, 1783), 154-155. 
widely influential. Burlamaqui's textbooks continued to inform the teaching of law in Geneva and made him into a now largely forgotten international celebrity in the late eighteenth century, as his works were translated into seven languages and saw 64 editions. ${ }^{22}$ In Principes $d u$ droit politique, for example, Burlamaqui argued that the power of the sovereign was limited by a supreme law, which is to foster public happiness, a notion that he derives directly from German Protestant natural law. ${ }^{23}$ A ruler who diverged from this ultimate aim would thereby automatically lose legitimacy, so that sovereignty would then ipso facto return to the nation, while the people always retain a right of resistance against despotic rule. ${ }^{24}$ Keen to eschew both tyranny and chaos, Burlamaqui cut a path between absolutist and democratic forms of government, proposing that sovereignty should be subject to "conventions" (i.e. fundamental laws) and parcelled out among various organs of government, which would hold one another in check. ${ }^{25}$ One easily recognizes the early outlines of the modern conception of the balance of power and the emerging concept of fundamental laws in his doctrine of limited monarchy. In his view, the civil freedom of individuals living under this political regime is akin to their natural freedom, but limited by the authority of the sovereign, i.e. the combined organs of government, which, however, have a mandate to act only in pursuance of the common good.

Opposed to Burlamaqui stood Rousseau, whose Social contract had, of course, been proscribed in the city and who had renounced his membership in the bourgeoisie, but who continued to intervene in public affairs through his writings, most prominently in the Lettres écrites de la montagne (1764) ${ }^{26}$ Contrary to Burlamaqui, Rousseau conceived of sovereignty as an inalienable and indivisible power vested in the people. This power manifests itself through the promulgation of laws, while the executive functions of the state pertain to the government, which acts merely as a servant of the sovereign, rather than as a part thereof. Laws represent an absolute expression of popular sovereignty, and they can accordingly be changed in

22. Burlamaqui found a particularly receptive ear in Thomas Jefferson, who incorporated his ideas in the Declaration of Independence and, in 1794, considered the project of transplanting the entire Geneva Academy to the United States (Borgeaud, 611). On the latter project, see Otto Karmin, Sir Francis d'Ivernois, 1757-1842. Sa vie, son œuvre et son temps (Geneva: Revue historique de la révolution française et de l'empire, 1920), 271-292.

23. For a detailed discussion of what Burlamaqui owes to Pufendorf, see Bernard Gagnebin, Burlamaqui et le droit naturel (Geneva: Frégate, [1944]). See also Alfred Dufour, "Die 'Ecole romande du droit naturel': ihre deutschen Wurzeln," in H. Thieme et al, eds., Humanismus und Naturrecht in Berlin-Brandenburg-Preussen (Berlin: Walter de Gruyer, 1979), 133-143.

24. [Burlamaqui, Jean-Jacques], Principes du droit politique, 1754 [no place], 37.

25. Ibid, 74.

26. For a discussion of Rousseau's political philosophy, see Robert Derathé, Jean-Jacques Rousseau et la science politique de son temps, $2^{\text {nd }}$ ed. (P.: Librairie philosophique J. Vrin, 1988). See also, with reference to the relations between Rousseau and Burlamaqui, Robin Douglass, "Rousseau's Critique of Representative Sovereignty: Principled or Pragmatic?" American Journal of Political Science, 57, 3 (2013): 735-747. 
conformity with the will of the people. ${ }^{27}$ The social contract must thus lead to an elective political regime, whether that be a democracy, an elective aristocracy, or an elective monarchy, depending on the size of the country (part 3, chp. 3) ${ }^{28}$ In this framework, the civil freedom of the individual is limited not by the organs of government, but directly by the will of the people, by way of its legislative authority. ${ }^{29}$ In Lettres écrites de la montagne, Rousseau defines civil freedom explicitly as obeisance to the law (as opposed to submission to individuals, for example magistrates), as the laws are the only objective and absolute expression of popular will. ${ }^{30}$

Bariatinskii, likewise, strongly hinted at the linkage between freedom, popular will, and the legal order, but he seemed more sceptical of popular will than Rousseau, and consequently more reliant on the role of unchanging fundamental laws and the importance of enlightened government:

Mais la France est-elle libre ou ne l'est-elle pas? Peut-elle déjà l'être, ou la liberté n'est-elle que le fruit d'un sage gouvernement, et d'une constitution solide et inébranlable?

To this question, he answered straightforwardly that absolute freedom is nothing but "la liberté du pays des chimères" as it cannot underpin society: "car au lieu d'être le principe vital d'un État, elle en est plutôt le bourreau" (10ob). A sentence he lifts without attribution from the Moniteur universel de Paris suggests that despotism is only marginally worse than anarchy:

Un des malheurs pour les peuples écrasés par le despotisme, c'est qu'ils ne peuvent retourner à la liberté sans passer par l'anarchie, le plus terrible des fléaux après la puissance arbitraire $(5) .^{31}$

However, in a later entry, he proposed that three kinds of freedom needed to be held in balance: political freedom, defined as subjection only to those laws one has helped to establish; civil freedom, which is the ability to do everything the law does not prohibit; ${ }^{32}$ and individual freedom, namely the confidence that person

27. Jean-Jacques Rousseau, Du Contrat social, in Euvres complètes, vol. 3 (P.: Gallimard, 1964), book 2, chp. XII, p. 394.

28. In Lettres écrites de la montagne, Rousseau tacitly accepts the premise that only the citoyens and the bourgeois assembled in the General Council constitute the sovereign, thus disenfranchising a large part of the Genevan population (including the so called natifs and sujets). For a commentary on this text, see Bruno Bernardi et al., eds., La religion, la liberté, la justice. Un commentaire des Lettres écrites de la montagne de Jean-Jacques Rousseau (P.: Librairie philosophique J. Vrin, 2005).

29. Rousseau, Du Contrat social, 365.

30. Jean-Jacques Rousseau, Lettres écrites de la montagne, in Euvres complètes, vol. 3 (P.: Gallimard, 1964), 842.

31. See Gazette nationale ou le Moniteur universel, no 29, (20 July 1789).

32. I translated "liberté civile" as "civil freedom" to differentiate it from the contemporary understanding of "civil liberties," which is closer to what Bariatinskii called "liberté individuelle." 
and property will not be infringed upon without due process (57ob). Clearly, Bariatinskii had no truck with absolutist social contract theory (Hobbes, Grotius, Pufendorf, etc.). In this triad of freedoms, civil freedom is presented as the more pernicious and in need of restriction, as "partout où la liberté civile est excessive les deux autres sont nulles" (57ob). To put it differently, the legal order needs to be sufficiently robust to hold civil freedom in check, and in order to do so, it needs on the one side to be legitimized by political, democratic participation in the promulgation of laws and on the other, to rest on the fundamental, inalienable rights of the individual.

In linking freedom to legality, popular sovereignty, and the rights of the person, Bariatinskii came close to the language of the Declaration of the Rights of Man and Citizen (1789). By emphasizing the role of fundamental laws, which provide safeguards against excessive civil freedom on the one hand, and against abuse by the sovereign on the other, Bariatinskii took a stance more in keeping with Burlamaqui and with the Declaration of the Rights of Man than with Rousseau, for whom any laws enacted by the popular will must always be right, even though they can change. And Bariatinskii also remained committed to the notion that ultimately the happiness of the people took precedence over their freedom and represented the ultimate criterion of legitimacy for the sovereign, a vestige perhaps of his intellectual debt to German natural law theory. Accordingly, in his analysis of the French Revolution, he withheld judgment, preferring to wait and see whether the legal architecture it put into place would secure the collective well-being of the nation (57ob).

Bariatinskii arrived in Geneva at a time of increased political unrest. Over the course of the eighteenth century, Geneva had punched above its weight in European affairs and assumed a visible position in debates among Enlightenment figures. The legacy of the Calvinist Reformation, the fame of Rousseau, the unique political system under which it functioned, often mythologized nostalgically as a kind of ancient republic, the alleged uncorrupted mores of the Genevans, and the economic dynamism of the city all combined to maintain Geneva in the international limelight..$^{33}$ The city also functioned as an international financial centre, which supplied loans abroad, notably to the French government and the French nobility. Yet social relations between its different orders were anything but harmonious. The city was composed of six different estates: the citoyens (i.e. the indigenous elite), the bourgeois (those who had inherited or purchased membership in the bourgeoisie), the habitants (foreigners given right of residence in the city), the domiciliés (foreigners with temporary domicile in the city), the natifs (descendants of resident foreigners, but born in the city), and the sujets (the peasants subject to feudal rule). By the end of the 1780 s, only male members of the first two estates, i.e. about 1,800 men out of a population of 35,000 , enjoyed political rights, but even for these two privileged groups, Geneva was far from democratic in the modern sense, as the legislative and

33. For an overview of Geneva's international reputation see Graham Gargett, "Genève au dix-huitième siècle: de la cité de Calvin au foyer des Lumières," in Siofra Pierse, ed., The City in French Writing: The Eighteenth-Century Experience (Dublin: University College Dublin Press, 2004), 136-161. Gargett calls the city one of the "crucibles" of new ideas (136). 
executive powers were vested in a small oligarchy, which controlled most political institutions in the city.

Without going into too much detail, Geneva's political order is best described as an aristo-democracy, a mixed form of government, theorized among others by Burlamaqui through his notion of an elective aristocracy "tempered by democracy." ${ }^{34}$ Legally, its basic modus vivendi was defined in the Règlement de l'Illustre Médiation of 1738, which formally acknowledged the sovereignty of the General Council, the assembly of the citoyens and bourgeois, but in practice submitted it to multiple restrictions. One of these was that, pursuant to Article 6 of the Regulation, nothing could be brought to the General Council that had not been previously approved by the other smaller councils, whose membership was largely self-recruited. ${ }^{35}$ The General Council could not even assemble except when officially called by the smaller councils. The Regulation aimed to hold in balance the "people" (the bourgeois) and the aristocracy (the patrician families), but without a right of legislative initiative, the sovereignty of the General Council was severely compromised.$^{36}$ Over the course of the eighteenth century, serious dissension emerged between the représentants, those among the General Council who made representations and claimed a greater say in the running of affairs, and the négatifs, the oligarchy that tended to reject all these representations. ${ }^{37} \mathrm{~A}$ failed insurrection by the natifs along with some citizens and bourgeois in 1782 resulted in the restoration of the ruling aristocracy but under French control. The social circles, which defined the city's public life, were abolished and, instead, a theatre was built to provide entertainment, breaking with the tradition of austere public mores and sumptuary laws that had given rise to a famous debate between d'Alembert (who touted theatre's civilising impact in his Encylopédie article on Geneva, vol. 7, 576-7) and Rousseau (who condemned the deleterious influence of theatre).$^{38}$ Political unrest resumed in January 1789, caused by a rise in bread prices and encouraged by revolutionary turmoil in France. In a concession to the polity, the circles

34. Burlamaqui, Principes du droit politique, 77. See Alois Riklin, "Jean-Jacques Burlamaqui und die Genfer Aristodemokratie," in Walter Haller et al., eds., Im Dienst an der Gemeinschaft: Festschrift für Dietrich Schindler zum 65. Geburtstag, (Basel: Helbing und Lichtenhahn, 1989), 639-652.

35. Règlement de l'illustre médiation pour la pacification des troubles de la République de Genève (Geneva, 1738). https://archive.org/details/BUSA297_085-4-

36. See Helena Rosenblatt, Rousseau and Geneva: From the First Discourse to the Social Contract, 1749-1762 (Cambridge: Cambridge University Press, 1997), 146-152 and Fabrice Brandli, Le nain et le géant. La République de Genève et la France au XVIIr ${ }^{e}$ siècle. Cultures politiques et diplomatie (Rennes: Presses universitaires de Rennes, 2012), 49-50.

37. For a description of Geneva's political order at the end of the eighteenth century and an analysis of the political demands of various parties and social estates, see Christian Alain Müller, "Nostalgie, révolution et régime républicain à Genève à la fin de l'Ancien Régime (1782-1792)," in Giovanni Bardazzi et Alain Grosrichard, eds., Dénouement des Lumières et invention romantique, (Geneva: Droz, 2003), 19-46.

38. For a brief account of the insurrection, see Eric Golay, Quand le peuple devint roi: Mouvement populaire, politique et révolution à Genève de 1789 à 1794 (Genève: Editions Slatkine, 2001), 33 . 
were again allowed, and by 1790 , the year Bariatinskii arrived in Geneva, civic activism and the dissemination of political pamphlets were flourishing. Among the prominent protestors featured Jacques Grenus, a lawyer and bourgeois close to the représentants who radicalized himself and became the main defender of the natifs. In the early months of 1790, he published five "Coups d'œil sur le passé et le présent," in which he demanded political equality across all estates, the separation of powers, a representative legislative assembly, a sparse, weakened executive branch of government, and simple laws. ${ }^{39}$ Political activism prepared the ground for three days of unrest on 13-15 February 1791, and discontent continued to fester throughout 1791, with further major unrest on 14 November 1791 . The political conflicts in the city culminated in December 1792 in a genuine revolution, which abolished the Ancien Régime in Geneva, introduced political equality for all Genevans, and led to the adoption of a democratic constitution in February 1794, followed by a brief period of revolutionary terror.

Bariatinskii wrote the draft of "Coup d'œil sur Genève" in his notebook. The placement of this text, its subject matter, and the virulence of its tone make it unlikely that it represented a pedagogical exercise mandated by a tutor. Instead, it must be seen as an extension of Bariatinskii's thoughts on the political upheavals unfolding before his eyes. There exists a clean copy of this text, written together with a longer, equally critical text on Italy (which also deserves attention) in a notebook entitled "Souvenirs d'Italie et de Genève, année 1792." ${ }^{40}$ Clearly this attractively prepared clean copy was aimed at dissemination, although there is no sign that Bariatinskii ever tried to publish it, nor are any other copies of it extant. We can surmise that he intended to circulate these two texts among his family and close friends, as was the practice among the aristocracy of his times. ${ }^{41}$ The fact that it was found in the archive of his son Aleksandr, rather than in his own personal archive, suggests as much.

Bariatinskii's "Coup d'œil sur Genève" takes a stern view of the city. The young student is generally (albeit not always) well informed. His descriptions of the social structure and political order of the republic are broadly accurate, if incomplete and somewhat tendentious. He is keenly aware of the mythical reputation of the city, and debunks some tenets of this myth, while accepting others. He identifies two main reasons for the evisceration of freedom in the city. The first is of a moral order and has to do with the arrogance, vanity, ambition, and prejudices of the ruling caste, which he calls aristocracy in the draft version and oligarchy in the clean copy.

39. See Golay, Quand le peuple devint roi, 61; Müller, "Nostalgie, révolution et régime républicain à Genève...," 33-43. Bariatinskii's title of "Coup d'œil sur Genève" was possibly prompted by Grenus's pamphlets, although titles beginning with "Coup d'œil sur..." existed before, famously in Charles de Ligne's Coup d'œil sur Belœil (1781) and, in the revolutionary context, in Jacques Necker's “Coup d'œil sur le discours prononcé par Necker à l'ouverture des États-généraux" (1789).

40. GIM OPI (Gosudarstvennyi istoricheskii muzei. Otdel pis'mennykh istochnikov - State Historical Museum. Department of Written Sources), f. 342, op. 1, d. 202.

41. See Gretchanaia and Viollet, "Si jamais tu lis ce journal...,”35-40. 
The second pertains to the political institutions of the city, which he characterizes as a political "medley" (macédoine) rather than a republic. Although he mentions briefly the General Council and acknowledges its right to elect the four syndics who run the city, he emphasizes the continuous erosion and abuse of democratic rights, which resulted in the fact that the two other organs of power, the Small Council and the Council of the Two Hundreds, conspired to monopolize all the legislative, executive, and judicial powers, which he deems an usurpation of sovereignty. He thus contrasts the contemporary oligarchic political system with its former incarnation, when the General Council played a greater role in the running of the city and about half of the political leaders came from outside the patrician elite. His description of the role of the General Council is brief, but largely correct. In 1768 the General Council had obtained the right to elect half of the Council of the Two Hundreds, but this right was removed in $1782 .{ }^{42} \mathrm{He}$ does not mention the right of representation (curtailed but not eliminated in 1782), which conferred members of the General Council the nominal entitlement to make formal demands to the Small Council, even if these demands were often summarily rejected. Nevertheless, as he correctly implies, the restoration of the sovereignty of the General Council was one of the main political aims of the citizens and bourgeois. ${ }^{43}$

Bariatinskii's' main focus, however, is not on political institutions, but on the moral character of the elite. In keeping with his analysis of the French Revolution, where he also laid the blame on the aristocracy, Bariatinskii highlights what he calls "aristocratic dizziness," a lust for power and distinction that borders on insanity and that he finds supremely ridiculous. In his view, it is the birth of an oligarchy that has destroyed the peaceful way of life and the ancient happiness of the Genevans. And it is this oligarchy that has undermined the democratic institutions of the city, partly by turning Geneva's vigorous debating culture into pettifoggery and chicanery. ${ }^{44}$ Although the pretentions of the oligarchy have sapped freedom and equality in the Republic, it did not succumb to ostentatious displays of wealth and to corrupted mores. The Genevans have remained thrifty and industrious, and Bariatinskii seems to accept the premise that public decency has been preserved..$^{45}$ Yet, ultimately, it is self-interest and individualism that solely motivate the oligarchs' behaviour, which, we can surmise on the basis of his views on the social contract, represents a breach of trust between the state and its elite. Calling protestors "true patriots,"

42. Müller, "Nostalgie, révolution et régime républicain à Genève...," 28; Golay, Quand le peuple devint roi, 35 .

43. Müller, "Nostalgie, révolution et régime républicain à Genève...," 29.

44. The 1791 version of "Coup d'œil sur Genève" refers explicitly and repeatedly to the aristocracy. However, when he prepared a clean copy of his text in 1792, Bariatinskii in several cases (albeit not all) substituted "oligarchy" for "aristocracy." In my analysis I refer to the initial version of this text, as it is the one more directly written under the influence of revolutionary events.

45. For a discussion of the evolution of mores in eighteenth-century Geneva, see Linda Kirk, "'Going Soft': Genevan Decadence in the Eighteenth Century," in John B. Roney and Marin I. Klauber, eds., The Identity of Geneva: The Christian Commonwealth, 1764-1864, (Westport: Greenwood Press, 1998), 143-154. 
Bariatinskii constructs an asymmetrical opposition between oligarchs and patriots, thereby casting doubt on the Genevan patriciate's dedication to the well-being of the city. It is clear from his writings that Bariatinskii conceived of aristocratic privilege as entailing a responsibility to act in the defence and furtherance of the common good of the republic, and it is this core principle that he sees contravened in the deportment of the Genevan oligarchy, which wears away the foundations of the polity like a "hidden file" (une lime sourde). In consequence, Bariatinskii indicts Geneva's government for being "so favourable toward the aristocracy, and so little apt to ensure the happiness of the Republic," the happiness of society remaining for Bariatinskii, as we have seen, the ultimate measure of the sovereign's legitimacy.

Bariatinskii is, of course, also attentive to matters of religious faith, a cornerstone of Geneva's international standing. He acknowledges the existence of religious freedom in the city and the importance of piety, but delineates a rational, if not rationalist attitude towards religion, the emergence of a shallow, desacralized form of piety. Ministers serve God and the world in equal measure and see no contradiction between the two. Calling them the "comedians" of Christianity seems to reproach them for discharging their ministry as a form of role-play, or an external calling. And Bariatinskii enthusiastically echoes d'Alembert's assertion that many Genevan priests no longer believe in the divinity of Christ. ${ }^{46}$

In describing the moral and religious attitudes of the Genevan elite, their habitus, as it were, Bariatinskii highlights traits that anticipate what Max Weber called the "Protestant ethic." Their devotion to worldly success, seen as a righteous calling, and to economic profit as an end in itself, their abidance by ascetic values of thrift and industry, their seeming disaffection from religious rituals, their indifference to the fine arts, their sacrifice of the pleasant to the useful, indeed their pursuance of self-interest instead of charity, all of these moral characteristics also feature in Weber's analysis of the Protestant ethic, underpinning his rationalization theory. ${ }^{47}$ The relentless efforts of what Bariatinskii calls a "frenetic aristocracy" bring to mind the systematic, methodical application of ethical precepts that Weber considers central to the Calvinist faith. ${ }^{48}$ This proleptic analogy with the Weberian critique of capitalism derives, in my view, from similarities between Weber and Bariatinskii's respective premises, notably their commitment to a degree of equality in the distribution of power and wealth and their critique of the capitalist inversion of values, whereby the pursuit of happiness is subverted into the

46. For a short account of Genevan theologians who turned to natural theology, attempted to provide a reasonable basis for the Christian faith, and de-emphasized the core mysteries of the faith and the fine points of scholasticism, see Marin I. Klauber, "The Eclipse of Reformed Scholasticism in Eighteenth-Century Geneva: Natural Theology from Jean-Alphonse Turretin to Jacob Vernet," The Identity of Geneva, 129-142.

47. Max Weber, The Protestant Ethic and the Spirit of Capitalism (1905; London: Routledge, 1992), 155-183. It goes without saying that in highlighting this juxtaposition, I in no way pass judgment on the historical validity of Weber's thesis.

48. Ibid, 117. 
pursuit of wealth as an end in itself. ${ }^{49}$ For Bariatinskii, it is a romanticized vision of the ancient republic, in which equal citizens work together to ensure the happiness of the community, i.e. pursue the common good, rather than seeking the individual accumulation of wealth, that underpins his rejection of capitalism.

It is important to point out that Bariatinskii attributes Geneva's economic success not only to the Calvinist ethic, but also to the diversity of the Republic, which he deems composed of three different communities, each characterized by a distinctive education, a "diversity of vocation," and a unique lifestyle. Although on account of his obsession with the elite, he fails to describe the culture of Geneva's popular neighbourhoods, one discerns in this passage a recognition that Geneva's economic livelihood relies less on the moral character of the Protestant aristocracy, than on the educational level and industriousness of its population at large, including the many foreigners who flock towards the city. Yet his lack of attention to the popular classes also betrays his blinders. He is a republican, not a democrat, and his premise of equality pertains to relations among those endowed with political rights, rather than among the people as a whole. What he decries in Geneva is the usurpation of power by an increasingly narrow oligarchy - which endangers liberty - along with the general lust for power and wealth, which saps the selfless ethos of genuine republicans. It is doubtful that Bariatinskii would advocate extending political rights to all inhabitants of the city. He has little to say about the natifs, let alone the sujets, and nowhere does he show any democratic proclivities in his writings.

Bariatinskii's brief comparison of the Genevans and the Jews reprises antiSemitic political rhetoric that emerged from French governmental depictions of the Genevans. Fabrice Brandli has documented how starting in the 1770s, Pierre-Michel Hennin - the French Resident in Geneva, i.e. the representative of the French government-deployed deprecating analogies between the Jews and the Genevans, focusing on three personality types seen as characteristic of Genevans: the speculating banker, the smuggler, and the rebel. All three types share the same vainglory and pursue their private interests at the expense of the common good of the Republic and its neighbours. The local madcaps and religious "fanatics" have been reinforced by the arrival of Huguenots from France, who share their unscrupulous and enthusiastic venality and thereby undermine the foundations of the political order. Hennin, however, writes as a monarchist and in support of the local oligarchic magistrates, who are loyal to France and threatened by the rise of these unscrupulous bourgeois who take advantage of the weaknesses of the republic as a political system. ${ }^{50}$ The similarity between this rhetoric and Bariatinskii's description of the ruling oligarchy - the "vanity" and "freneticism" of the

49. For Weber's critique of capitalism, I am drawing on Michael Löwy's insightful reconsideration of the hackneyed opposition between Weber and Marx in Michael Löwy, La cage d'acier: Max Weber et le marxisme wébérien (P.: Stock, 2013). See in particular Löwy's discussion of Weber's critique of the capitalist system in 43-48.

50. See Brandli, Le nain et le géant, 55-57, 63-64, 133-141. 
ruling "hotheads" - is striking. But contrary to Hennin, Bariatinskii applies this language to the ruling patricians, those who have usurped the political rights of the citoyens and bourgeois and thereby despoiled freedom in the Republic. In so doing, he co-opts these representations in defence not of monarchy, but of the nostalgic ideal of an original, uncorrupted, peaceful republic which once enjoyed the fruits of happiness.

Taken together, Bariatinskii's assessment of the political conflicts in Geneva remains paradoxical. While his analysis is inspired by the republican ideal, his dismissive comments about political rhetoric in the city suggests a misunderstanding of the importance of its debating culture, an important aspect of its political system, its public sphere. Furthermore, even though he perceptively analyses the evisceration of liberty, which he understands as inextricably tied to sovereignty, he fails to validate the political aspirations of the natifs, the bulk of the Genevan population, towards admission to the bourgeoisie and participation in the political process. Even his economic views remain paradoxical, his disdain for the individual pursuit of profit, which aligns him with the traditional noble disparagement of self-interest, contradicting his praise for the economic dynamism of the city as a whole..$^{51}$ One senses that his affection for the republican paradigm, with its moral imperative of acting on behalf of the common good, stands in the way of a coherent analysis of the historic shifts that unfold before his own eyes.

Bariatinskii's terminological hesitation between aristocracy and oligarchy is itself symptomatic. The social tensions he observes in Geneva serve as a screen upon which he projects his anxieties about the legitimacy of his own estate. Calling the Genevan patriciate an aristocracy brings it into the orbit of his own self-criticism or self-doubt as a member of the Russian aristocracy. It bears mentioning that the Genevan oligarchy did not consist of a legally constituted nobility (whether of the sword or of service) inheritable by birth, but rested on holding high office in the city government. Bariatinskii is blind to this distinction, or unconvinced of its importance. When he derides the petitesse of the Genevan oligarchy, one could be tempted to upbraid him for his condescending views of the vernacular elite, stirred by the pride he could take in the longer lineage and greater wealth of the Russian aristocracy. But this would mean to ignore the sharp criticisms Bariatinskii reserved for his own kind in his other writings. It is worth noting the virulence of his views on the Russian (noble) national character, undoubtedly inspired by Rousseau and betraying jaundiced views of court society:

Le caractère du Russe est faux. Son élément est l'intrigue. Bas et rampant, fier et superbe, véritable caméléon, il est susceptible de tout, et n'est propre à rien. Les Russes se ressemblent tous, non qu'ils ayent un caractère national, mais

51. By way of comparison, for a discussion of the tension in England between the search for productivity and profit on one side, and the requirement for well-bred gentlemen farmers to rise above self-interest on the other, see Stephen Bending, "The Improvement of Arthur Young: Agricultural Technology and the Production of Landscape in Eighteenth-Century England," in David E. Nye, ed., Technologies of Landscape: From Reaping to Recycling, (Amherst: University of Massachusetts Press, 1999), 241-253. 
parce qu'ils imitent tous de même. Le seul talent qu'ils possèdent est celui de l'imitation (101).

Bariatinskii was obsessed with a contradiction at the heart of aristocratic identity, the simultaneous consciousness of superiority and the need to abase oneself before higher-placed individuals in court society. As he contemplated his future, he outlined three existential paths open to him. The first two, inspired by ambition, were either to instigate a revolution, or to rise socially by way of "courbette," that is, by courting high-placed individuals. The third, which he associated with Mirabeau and deemed inspired by philosophy and virtue, was to "think as a free man in a free country" and to contribute with all his might to "enlighten humanity about its own interests" (83ob). The options he formulated here are in themselves telling. The first implies a radical break with the habitus of his social estate, the second total adaptation to it. To escape this uncomfortable binary opposition, Bariatinskii looked to philosophy, the world of Enlightenment ideas, to carve out an autonomous, self-determining identity that would help him disregard polite conventions and empower him to serve the common good of humanity. What is significant here is the notion that his calling is both to affirm and protect his own freedom, even if in defiance of his immediate social environment, and to contribute to the enlightenment of humanity. Bariatinskii conceived of his life as a form of public service that required a degree of autonomous self-fashioning.

Although he expressed the desire to pursue this third path, his subsequent life shows that until his abrupt retirement in 1812, which allowed him to recover a degree of independence (or the illusion thereof) by settling on his estate and engaging in agricultural improvement, he could not avoid the psychologically debilitating practice of courbettes. His views on the Russian aristocracy remained unchanged, and until his death in 1825, he continued to write scathing descriptions of the lifestyle of fellow aristocrats and landowners.$^{52}$ His critique of the Genevan aristocracy must thus be seen in the larger context of a torturous exploration of what it means to be an aristocrat at a time when this estate had become a "faction expirante," as he put it in his description of Geneva. At the risk of undue extrapolation and despite the obvious differences between the Genevan and the Russian aristocracies, we can conclude that what transpires through his analysis of the Genevan case is a degree of self-questioning. He seems keenly aware that as a representative of this privileged estate, he is trapped in intractable contradictions. The extent to which Bariatinskii systematically blamed his social peers for the miseries of the world, whether it was in his analysis of the causes of the French Revolution, the backwardness of Russia, or the civil strife in Geneva, finds its origins in his consciousness that the aristocracy did not live up to its part of the social contract, the requirement

52. In 1815 Bariatinskii developed an educational plan for his son, explicitly designed to protect him from the nefarious influence of court society and at the same time to equip him to make a substantial contribution to his country. This plan was published in Russian translation in A.L. Zisserman, Fel'dmarshal Kniaz' Aleksandr Ivanovich Bariatinskii, 1815-1879 (M : Universitetskaia tip., 1888), 4-10. 
to render dues to its country. The ideas he adopted from German natural law theory conflicted fundamentally with the aristocratic habitus and opened up deep tensions at the heart of his sense of self.

Bariatinskii's virulent analysis of Geneva sheds contrastive light on Nikolai Karamzin's description of the city in his Lettres of a Russian Traveller. ${ }^{53}$ Even though in Iurii Lotman's account, in the 1790s Karamzin privately embraced the French Revolution to the extent that he could see it as the manifestation of utopian enlightened reason, he clearly rejected popular civic unrest on the streets. This mistrust of untamed manifestations of revolutionary fervour underpins his depiction of revolutionary events in Strasburg, for example. In Geneva he shows little sympathy toward the protestors and little awareness of their agenda. ${ }^{54}$ Karamzin arrived in the city about a year before Bariatinskii, in autumn 1789, staying until spring 1790, which means that he witnessed only the early days of the Genevan revolution. Street unrest had begun in January 1789. It had involved fatalities on both sides and prompted the government to issue an edict of pacification in February 1789, which allowed the reopening of the circles and pronounced an amnesty for the political exiles of $1782 . .^{55}$ The period during which Karamzin resided in the city witnessed a flurry of political pamphlets from all parties, but little actual unrest ${ }^{56}$ His evocation of the city generally stays clear of political considerations, with the exception of a few subtle remarks. He visits some circles and reports that the conversation mostly revolved around the situation in Paris, not out of political interest, but because wealthy people had lent millions to France and feared that the country would declare bankruptcy. Needless to say, it is the cercles of the elite that Karamzin frequented, and if he chides them for anything, it is not for their elitism, but their parochialism, in particular their disinterest in Russia's wars against Turkey and Sweden. ${ }^{57}$ Karamzin gives pride of place in his account to Charles Bonnet (1720-1793), a prominent naturalist, who disapproved of Rousseau's critique of the city and praised the diffusion of enlightenment among the bourgeois middle

53. Bariatinskii, of course, could not have known Karamzin's Letters, and although both writers were intensely preoccupied with the Revolution, there is much that differentiated them, notably their social background, as well as the audience they aspired to address through their writings. Nevertheless, the comparison is instructive, as Karamzin's tone defines, as it were, the limits of what he thought could be stated in print, while Bariatinskii's text represents the unguarded musings of a member of the elite writing for his own narrow circle.

54. For a brief discussion of Karamzin's relationship to the French Revolution in the context of previous scholarly views thereof, see Rodolphe Baudin, Nikolaï Karamzin à Strasbourg: Un écrivain-voyageur dans l'Alsace révolutionnaire (1789) (Strasbourg: Presses Universitaires de Strasbourg, 2011), 162-170. Baudin rightly underscores that in line with the idyllic code he projects upon reality, Karamzin plays down the Revolution in the Letters of a Russian Traveller, but he is too quick to conclude that this reflects Karamzin's wholesale rejection of the Revolution (168).

55. Golay, Quand le peuple devint roi, 213.

56. Ibid, 54-55.

57. Karamzin, Pis'ma russkogo puteshestvennika, 160. 
classes as well as among women. ${ }^{58}$ Karamzin himself corroborates this impression, remarking that hairdressers cite Voltaire by heart, while ladies are learning about the secrets of the Creation..$^{59}$

Karamzin was aware of the tense political situation in the city and claims in a letter of 23 January 1790 that "discord is beginning," by which he must have referred to the events that had unfolded a year earlier. Yet he shows little understanding of the protestors: "strange people," he claims, "they live in peace and contentment, and still want something." ${ }^{60}$ As he then describes a service he attended in the cathedral of St. Pierre, he summarizes sympathetically the patriotic sermon of the preacher, who affirmed the general happiness of the Republic and called on its inhabitants to cherish social harmony and peace, which alone can safeguard the security of all. In a subsequent letter, he refers with relief to the sanction given by the foreign powers (France, Berne, and the Kingdom of Savoy) to the edict of pacification of February 1789 and describes a meeting of the General Council, during which "all Genevans" voted in the new syndics. ${ }^{61}$ As Rousseau before, he mistakes the electorate of the General Council for the Genevan population as a whole, displaying ignorance of one of the main demands of the protestors (such as easier access to the bourgeoisie and equal rights for the natifs and the sujets). Eager to preserve social harmony, Karamzin is all too happy for political tensions to be papered over by token concessions from the government. Finally, as he is about to leave the city for France, he condescendingly belittles the city as a "beautiful toy," while echoing several clichés about it:

Пусть цветет маленькая область их под тенью Юры и Салева! Да наслаждаются они плодами своего трудолюбия, искусства и промышленности! Да рассуждают спокойно в серклях своих о происшествиях мира, и пусть дамы их загадывают загадки глухим баронам! Пусть все европейцы с севера и юга приезжают к ним на вечеринки играть в вист по гривне партию и пить чай и кофе! Да будет их республика многие, многие лета прекрасною игрушкою на земном шаре. ${ }^{62}$

58. In her article on Karamzin's stay in Geneva, Svetlana Gellerman closely analyses the writer's relations with Bonnet. See Svetlana Gellerman, "Karamzine à Genève: notes sur quelques documents d'archives concernant les Lettres d'un voyageur russe," in Monika Bankowski et al., eds., Fakten und Fabeln: schweizerisch-slawische Reisebegegnung von 18. bis zum 20. Jahrhundert, (Basel and Frankfurt-am-Main: Helbing \& Lichtenhahn, 1991), 73-90.

59. Ibid, 169. Many travellers marvelled at the high level of education of the Genevan population. Aleksei Andreevich Golitsyn, who travelled through Geneva in 1782 noted that "Les habitans de Genève ont le libre usage de la Bibliothèque publique, et par ce moyen il leur est facile non seulement de cultiver, mais encore d'étendre les connaissances générales qu'ils doivent à leur première éducation." Golitsyn, Aleksei Andreevich, "Description de mes voyages. 1780-1787," GPB, Fr Q IV 198/1, 122. He mentioned the political situation only briefly.

60. Karamzin, Pis'ma russkogo puteshestvennika, 170.

61. Ibid, 183.

62. Ibid, 188. 
Social life in the cercles in this account amounts to little more than anodyne entertainment spiced up with intellectual pursuits for good form. Drinking tea and coffee, instead of hard liquor, while gambling for menial sums and playing charades, conveys a mildly ironic picture of a carefree virtuous upper-class existence among an otherwise industrious polity. ${ }^{63}$ What it does not, is give an idea of the deep social tensions that simmered and were about to ravage the city, ultimately leading to a brief interlude of revolutionary terror in 1794. Much as he had done in his description of Strasbourg, Karamzin plays down manifestations of revolutionary sentiments. ${ }^{64} \mathrm{He}$ seems keen to portray Geneva as a historical enclave sheltered from the upheavals he had witnessed in Strasbourg and subsequently would observe again in Lyon and Paris. His affection for the idyll, which leads him to cast a prettifying veil over reality, trumps the historical intuition of the future historiographer.

But not all Russian travellers were as keen to gloss over the revolutionary significance of the unfolding events. Pavel Stroganov, the son of the grandee Aleksandr Stroganov, who had himself travelled extensively through Europe, was more forthright in his evocation of revolutionary events. As part of an educational journey in the company of his governor Gilbert Romme, the future Montagnard, he stayed in Geneva for two years between 1786 and 1788, during which time he also travelled through Switzerland and the Savoy Alps. His visit to Geneva coincided with a period of calm and his letters reveal nothing about the political situation in the city. Apart from his private letters, in which he evoked his everyday life and studies, the only travel description of Geneva in his hand is entirely devoted to watch-making. ${ }^{65}$ It is generally assumed that his political awakening took place in 1789 , when he attended the meetings of the General Estates in Paris. However, the travel notes of his journey through Switzerland in 1787 contain detailed descriptions of the political system of various towns, notably Mulhouse and La Chaux-de-Fonds, in which he analyses their respective electoral systems, the competences of various political bodies, the role of the bourgeoisie, and taxation issues ${ }^{66}$ It is thus inconceivable that Stroganov would have paid no attention to the political modus vivendi in Geneva. His governor, furthermore, took a dim view of the mores in Geneva, citing

63. On foodways in Karamzin's Letters, see Rodolphe Baudin, "Portrait du Voyageur en mangeur sensible : nourriture et pratiques de consommation dans les parties allemande et suisse des Lettres d'un voyageur russe de Nikolaï Karamzine," in Rodolphe Baudin, ed., Manger russe (P., Institut d'Études slaves, 2015), 39-64.

64. On Karamzin's depiction of revolutionary upheaval in Strasburg and on the idyllic mode through which he filters reality in the Letters, see Baudin, Nikolaï Karamzin à Strasbourg, 131-170.

65. "Zhurnal puteshestviia po chuzhim kraiam Grafa Pavla Aleksandrovicha Stroganova v 1785 godu. Knizhka 3,' RGADA (Rossiiskii gosudarstvennyi arkhiv drevnikh aktov - Russian State archive of ancient acts), f. 1278, op. 1, ed. khr. 347. He notes that women and children are also involved in the production of watches.

66. "Zhurnal puteshestviia po chuzhim kraiam Grafa Pavla Aleksandrovicha Stroganova v 1785 godu. Knizhka 2," RGADA, f. 1278, op. 1, ed. khr. 346 Despite the title of this manuscript, the journey actually took place in 1787 . 
several incidents of cruel child neglect, which, in his view "annoncent à quel point en sont les mœurs, et ce qu'on doit penser de cette pureté des mœurs qui distingoit jadis les Genevois." 67

In Paris, Stroganov became an attentive observer of the French Revolution and developed political views quite similar to Bariatinskii's. ${ }^{68}$ Referring to the debates at the National Assembly and using a pseudonym for Stroganov meant to protect his anonymity, Romme wrote that "Nous ne manquons pas une seule séance à Versailles. Il me semble que pour Otcher (et non plus pour le comte Stroganov, soit dit en passant), c'est une excellente école de droit public. Il suit les débats avec un vif intérêt. C'est le sujet constant de nos conversations. Les grandes questions touchant la vie de l'État absorbent à un tel point notre attention et tout notre temps, qu'il nous devient à peu près impossible de nous occuper d'autre chose." ${ }^{\prime 9}$ Stroganov's civic education quickly turned into political conviction. He joined the Club of the Jacobins and claimed that he spoke twice at the bar of the National Assembly. ${ }^{70}$ But when reports of his activities came to the attention of the empress and her entourage, his father was ordered to call him back to Russia without delay, and so Stroganov left Paris and returned to Russia in December 1790.

As a reaction to the standard Soviet thesis that Stroganov took part in the French Revolution, Aleksandr Chudinov and Vladislav Rjéoutski have played down the extent of Stroganov's involvement and the depth of his revolutionary convictions. ${ }^{71}$ However, it is clear that Stroganov faced inner tensions reminiscent of Bariatinskii's contradictions. As he put it quite succinctly, "je ne suis point un séditieux, mais j'aime la justice et je me range de son côté partout où je la trouve." While he expressed his admiration for the Revolution in letters to his entourage, he also reassured his father that he thought a similar revolution would be "impraticable en Russie." He claimed that he was under no illusions about "les horreurs du despotisme" and that "la voix agréable de la liberté s'est fait entendre trop voluptueusement à mon oreille pour que je puisse désormais endurer patiemment les sons aigres

67. Gilbert Romme, Notes scientifiques et anecdotes, 1782-1788 (Clermont-Ferrand: Presses universitaires Blaise-Pascal, 2009), 190. Romme also wrote to Aleksandr Stroganov that "Malgré les troubles qui ont éloigné de Genève plusieurs personnes intéressantes, l'académie offre encore tous les maîtres dont nous pouvons avoir besoin." Nicolas Mikhailovitch, Le comte Paul Stroganov, 3 vols (P.: Imprimerie nationale, 1905), vol. 1, 170.

68. On the educational journeys of Russian noblemen to France, see Wladimir Berelowitch, "La France dans le 'Grand Tour' des nobles russes au cours de la seconde moitié du XVIII siècle," Cahiers du monde russe et soviétique "Noblesse, État et société en Russie", 34, 1-2 (January-June 1993):193-209, ed. by Wladimir Berelowitch.

69. Nicolas Mikhailovitch, Le comte Paul Stroganov, vol. 1, 39-40.

70. Letter to Demichel, November 1790, Mikhailovitch, Le comte Paul Stroganov, vol. 1, 189.

71. Rzheutskii, Chudinov, "Russkie 'uchastniki' frantsuzskoi revoliutsii," 6-45. The same argument is presented in greater detail in A.V. Chudinov, Frantsuzskaia revoliutsiia: istoriia i mify [The French revolution: history and myths] (M.: Nauka, 2007), 237-279 as well as in Alexandre Tchoudinov, Les Archives de l'Est et la France des Lumières, vol. 2, Inédits, ed. Georges Dulac et Serguei Karp (Ferney-Voltaire: Centre international d'étude du XVIII ${ }^{\mathrm{e}}$ siècle, 2007), 682-695. 
du despotisme." ${ }^{72} \mathrm{He}$ accepted the injunction to return to Russia out of filial obligation to his father, but worried that he would not be able to render service to his contemporaries, as he would likely be silenced and side-lined. In a clear jab at Catherine, he stated that

je ne me sens pas disposé à exposer ma vie pour le caprice d'une femme ambitieuse; mon sang et ma fortune appartiennent à mes concitoyens; qu'ils en disposent, ils ne trouveront point en moi un récalcitrant. ${ }^{73}$

The displacement of the aristocratic duty of service from the ruler to fellow citizens signalled a paradigm shift in his mind. His identification and allegiance were no longer with the autocrat, whom he called a despot, but with the nation as a whole. Furthermore, he now faced the problem of maintaining his integrity. To his end, he resolved to continue to express his views forthrightly, stating in a letter to Romme that

j'aimerais toujours mieux être victime du despotisme avec une conscience pure que de l'avoir bourrelée et déchirée de remords pour éviter ses coups, ils doivent se briser contre l'honnête homme comme les flots de la mer contre le rocher, qui reste inébranlable dans son sein. ${ }^{74}$

Just like Bariatinskii, he looked for ways to shore up his inner convictions in the face of external political pressure, conscious that he needed psychologically to withstand "le spectre hideux du despotisme" and to become "le conservateur de [mon] innocence au milieu de la corruption la plus effrénée." 75

Bariatinskii and Stroganov were both born in 1772 and belonged to the same generation. For them, the spectacle of the Revolution became a watershed experience, which divided their lives into a before and an after. As they tasted the fruits of liberty and developed firm political convictions based on values they deemed universal (justice, reason, freedom, etc.), they became increasingly critical of the behavioural norms in court society and re-defined themselves as patriots of their country, rather than subjects of their ruler. Of course, they were not the first to complain about the instability of court society, but now they deployed a political language to buttress their rejection of the deleterious effects of patronage. ${ }^{76}$ For both of them, what resulted from the crisis was a moral problem: how to retain their integrity in a society that demanded abject forms of submission, how, in their

72. Letter to Demichel, November 1790, Mikhailovitch, Le comte Paul Stroganov, vol. 1, 189.

73. Ibid, 189-190.

74. Letter to Romme, 11 december 1790, Mikhailovitch, Le comte Paul Stroganov, vol. 1, 191.

75. Letter to Romme, 14 december 1790, Mikhailovitch, Le comte Paul Stroganov, vol. 1, 193.

76. On the perception of court society among the aristocratic elite, see Andreas Schönle, "The Instability of Time and Plurality of Selves at Court and in Society," in Schönle, Zorin, and Evstratov, eds., The Europeanized Elite in Russia, 281-299. 
words, to "think as a free man in a free country" and to become the "guardian of [their] innocence." Despite their high-flown youthful rhetoric, neither, of course, would be successful in protecting this redefined sense of honour, although both remained committed, in one way or another, to furthering reform in their country, Bariatinskii through his work as a reforming agronomist and Stroganov in advancing a political programme in Alexander I's "Secret Committee." Both turned against their social peers in the course of their activities. Bariatinskii despised the nobility's chameleonic behaviour, as we have seen, while Stroganov called it "la classe la plus ignorante, la plus crapuleuse et dont l'esprit est le plus bouché" in official meetings of the Secret Committee. ${ }^{77}$ The fact that they remained aristocrats and continued to partake of the privileges of their estate, while nursing sharply critical views of the noble habitus, laid the seeds of a psychological predicament, the conflict between social identity and personal conviction, which, to all appearances, they were the first generation to experience, but which remains, in one form or another, a recurrent phenomenon in Russian society to this day. ${ }^{78}$

So what is the ultimate significance of Bariatinskii's "Coup d'œil sur Genève"? Beyond the brief description of political structures, this text can be seen as a personal meditation on the nature of aristocracy and its relations to society, a meditation conducted by someone who would eventually inherit an estate of 35,000 souls. In the first instance, it reveals that contrary to Soviet tenets, a republican political consciousness also emerged in Russia independently of Radishchev's influence and among the very top layers of the elite. Secondly, it shows that this critical consciousness was expressed not as an abstract argument against autocracy, but as a moral condemnation of the aristocracy and, by extension, the nobility as well as court society. Accordingly, for Bariatinskii, political consciousness took the form, initially, of self-education and subsequently, of an intent to spread "enlightenment" among his peers, rather than of a commitment to work towards political or institutional reform. In his later years, his self-justification was to present himself as an enlightened landlord who puts his estate economy on an imposing but rational footing, hoping that his neighbours would be inspired by his commendable example to follow suit. Political consciousness thus became a moral and mundane project, which largely left the task of political and social reform unaddressed. Bariatinskii was not alone in this. Other wealthy landowners, too, searched for a rational means to improve the lot of the serfs on their estates, and derived moral legitimacy for their elite existence from this effort. ${ }^{79}$ In parallel with the rise and subsequent radi-

77. Mikhailovitch, Le comte Paul Stroganov, vol. 2, 62.

78. It culminated in forms of self-loathing and self-laceration, which Dostoevsky explored in Notes from the Underground and other works, and resurfaces now with renewed acuteness in the relations between civic-minded individuals and the state in Putin's Russia. For an analysis of this problematic in the late Soviet period, see Alexei Yurchak, Everything was Forever, Until It Was No More: The Last Soviet Generation (Princeton: Princeton University Press, 2006).

79. See, for example, with regard to the Sheremetev family: Tracy Dennison, The Institutional Framework of Russian Serfdom (Cambridge: Cambridge University Press, 2011). The 
calization of the secret societies, which culminated in the Decembrist uprising but remained a marginal phenomenon, subjective consciousness and everyday life became diffuse sites of political investment, in ways that did not always register in the historical record, but are nonetheless relevant, as they imperceptibly unmoored the elite sense of self. There is no space here to analyse in detail Bariatinskii's actions as he embarked on a transformation of his estate of Mar'ino in the Kursk province and eventually settled into the role of an improving resident landowner. Suffice it to say that this effort became his major preoccupation in life. ${ }^{80}$ For Bariatinskii everyday life was not a sphere of unreflected immediacy, nor a power-infused system of norms and conventions, but a task to confront, a challenge to fashion a lifestyle that was at once aesthetically appealing, morally commendable, and economically sustainable. ${ }^{81} \mathrm{He}$ succeeded on the first count and failed on the last. The moral offshoot of his actions is difficult to judge, although during the construction of his mansion, he clearly made the life of his serfs more miserable, despite his attempts to alleviate their lot. But in Russian society the notion that in the absence of hope for political change, everyday life becomes an arena where reformist velleities should translate into meaning-bearing, small-scale action-an arena to re-invent practice, deploy resistance, and prove one's allegiance-was destined to endure.

School of Languages, Linguistics, and Film

Queen Mary University of London

a.schonle@qmul.ac.uk

plans and practices of reformist landowners have been analysed in detail by Michael Confino, Systèmes agraires et progrès agricole: L'assolement triennal en Russie auX $X V I I I^{\mathrm{e}}-\mathrm{XIX} \mathrm{X}^{\mathrm{e}}$ siècles (P.: Mouton, 1969). See also Michael Confino, Domaines et seigneurs en Russie vers la fin du XVIII $e^{e}$ siècle (P.: Institut d'études slaves, 1963).

80. For an analysis of Bariatinskii's re-fashioning of his estate, see Andreas Schönle, "Selffashioning, Agricultural Improvement, and Enlightenment Practice: I.I. Bariatinskii's Reforms of the Country Estate," in Schönle, Zorin, and Evstratov, eds., The Europeanized Elite in Russia.

81. For a survey of various philosophies of everyday life, see Claire Colebrook, "The Politics and Potential of Everyday Life," New Literary History, 33, 4 (2002): 687-706. For a recent discussion of the historiography of everyday life in Russia, see David L. Ransel, "The Scholarship of Everyday Life," in Choi Chatterjee et al., eds., Everyday Life in Russia Past and Present (Bloomington: Indiana University Press, 2015), 17-34. 


\section{APPENDIX}

\section{I.I. BARIATINSKII, « COUP D’EIL SUR GENÈVE $»^{1}$}

[2]

«Et qui de vous, par ses inquiétudes peut ajouter une coudée à sa taille ?» (Mt. 6, 27)

On parle beaucoup de liberté à Genève: c'est plutôt parce qu'on l'admire que parce qu'on en jouit. Ces espèces de républicains que l'Europe commence à imiter, sont moins libres que ceux à qui ils font envie. La défiance, l'ambition et une foule de causes attentatoires à la liberté et au repos empoisonnent les sources de la tranquilité publique et de la prosperité nationale. Il n'y a pas de Genevois qui ne se compare [croie être semblable] à un ancien Romain. Si la vanité fait des malheureux, c'est à Genève qu'il faut chercher ses victimes!² [2ob] Jean-Jacques a dit

1. "Coup d'œil sur Genève" exists in two versions. The first, from Bariatinskii's notebook "L'année 1791. Ecrits du Prince Ivan Ivanowitch Bariatinsky" (mistakenly catalogued in the archive as "Chernoviki, zapiski, zametki, rassuzhdeniia I.I. Bariatinskogo. 1871 god," RGB OR, f. 19, op. 2, papka 253, d. 1.,1.71-72) was written when Bariatinskii was in Geneva, most likely around November 1791 . He then prepared a second, clean copy, written together with a longer equally interesting text on Italy in a notebook entitled "Souvenirs d'Italie et de Genève, année 1792" (GIM OPI, f. 342, op. 1, d. 202). As he prepared the clean copy, he undertook grammatical and stylistic revisions, as well as introduced a few substantive changes. The main difference lies in the substitution in several, but not all instances of aristocratie or aristocrate for oligarchie or oligarque. This may have happened either for the sake of historical accuracy, or because Bariatinskii had become more forgiving of the aristocracy as a social estate in the interval. In this second version, he also deleted a few sentences, which slightly softened the tone of his indictment of the Genevan "oligarchy." To give a sense of both texts, I have used the clean copy of 1792 as the basis for this publication, but restored in square brackets words or clauses from the draft version that were omitted or substituted in the clean copy. However, my interpolation of fragments of the 1791 version only pertains to changes of substance, not grammatical corrections or stylistic adjustments. Bariatinskii added the epigraph from Mt. 6, 27 to the clean copy, probably in reference to the frénétique oligarchie's appetite for power. My transcription preserved Bariatinskii's spelling, but normalized his punctuation and capitalization.

2. Bariatinskii contradicts here the political myth of the Genevan Republic, reflected, for example, in d'Alembert's statement that "le gouvernement de Genève a tous les avantages et aucun des inconvéniens de la démocratie," Encyclopédie, ou Dictionnaire raisonné des sciences, des arts et des métiers, vol. 7 (P., 1757), 576. Even Rousseau, from his "Dedication to Genevans" in the Discours sur l'origine de l'inégalité to the Lettres écrites de la montagne, could not help idealize Geneva as a virtuous, egalitarian, democratic, and free society. See Jean-Daniel Candaux, "Introduction. Lettres écrites de la montagne," in Jean-Jacques Rousseau, Euvres complètes, vol. 3 (P.: Gallimard, 1964), cxcvii-cxvviii. A key ingredient of this political myth was the notion that in its ancient political system, the "people" exercised complete sovereignty through the Conseil Général, powers that were then steadily eroded and that the bourgeois protestors wanted restored. 
qu'un peuple ne devient célèbre que quand sa législation commence à décliner ${ }^{3}$. Sous ce rapport Genève peut prétendre à vivre dans la postérité. Le corps politique est à l'agonie, et les médecins sont des oligarques [aristocrates]. Tout est bien calculé pour sa mort prochaine.

Les Genevois sont heureux, puisqu'ils prennent leur horizon pour les bornes $\mathrm{du}$ monde. De leur suprême élévation, où les met leur fol orgueil, ils dédaignent les grands des autres pays et tâchent de les abbaisser par une certaine manière d'être législatrice, qui semble les dédommager de leur propre petitesse ${ }^{4}$. Leur politesse est réfléchie, étudiée, impérative.

Genève a la fièvre de l'insurrection presque tous les soirs ${ }^{5}$. C'est un tribut que la nation paie à l'oligarchie [l'aristocratie], à cette soif de dominer qui est la base de son caractère. Les Genevois sont autant de petits Césars qui voudraient être plutôt les premiers dans un village que les derniers dans une ville. [3]

3. See Jean-Jacques Rousseau, Du contrat social, in Euvres complètes, vol. 3, 381.

4. The Republic of Geneva, helped by an alliance signed in 1584 with the Protestant cantons of Bern and Zurich, asserted itself against the intentions (and at times occupation) of the dukes of Savoy, who recognized the city-state only in 1754. In the eighteenth century, Geneva was an independent state, albeit under direct influence from France, whose representative, the "Resident," took an active role in political matters. The alliance with Bern and Zurich continued to safeguard its independence from the Kingdom of Sardinia (i.e. the House of Savoy), which extended as far as the town of Carouge, in the immediate vicinity of Geneva. At times, the city successfully played the Swiss cantons against France, but after the insurrection of 1782, when an alliance of some bourgeois and natifs overturned the government, the foreign powers intervened together, and Geneva fell under direct control of Paris. Only in 1789, with the beginning of the French revolution, did Geneva recover some of its independence. The revolutionary events which started in 1789 resulted in the proclamation of a series of increasingly liberal edicts and codes, which struck a balance between concessions to the demands of the bourgeois and natifs and the need to re-affirm Geneva's distinct institutions against perceived and real attempts by France to annex the city.

5. Street unrest generally took place in the evening, when members of the rebellious political circles marched in the city while chanting revolutionary songs such as the "Ça ira." So did the protests of 12-14 February 1791, along with the marches, among others, that took place on 31 October and 14 November of the same year, when the natifs returned to the city before the closing of the gates after a day of carousing in the countryside. After February 1791, street disturbances became a regular occurrence. See Eric Golay, Quand le peuple devint roi. Mouvement populaire, politique et révolution à Genève de 1789 à 1794 (Genève: Editions Slatkine, 2001), 230, 236-237, 248-254. 
Genève est pavé d'avocats. C'est l'antre de la chicane. L'esprit ergoteur est le seul que les Genevois possèdent ${ }^{6}$. L'intérêt est leur Dieu ${ }^{7}$. S'ils pouvaient lui élever un temple, l'herbe croitrait bientôt dans celui du Dieu des Chrétiens.

Genève renferme dans son sein tout ce que les préjugés de la naissance ont de plus ridicule et de plus corrupteur, tout ce que le vertige Aristocratique peut inspirer de folle présomption et de puérile vanité, et tout ce qu'une concurrence éternelle au droit de citoyen a de plus funeste dans ses effets ${ }^{8}$. Cet âtome politique est lui même un composé de trois villes essentiellement différentes les unes des autres, [par leur éducation], par leurs opinions, par la diversité de leur vocation, et même par leur manière de vivre ${ }^{9}$. Ce n'est pas une république. C'est une macédoine de tous les gouvernements connus, sur laquelle plâne impérieusement une frénétique oligarchie [aristocratie $]^{10}$. [3ob]

6. "By "avocats" Bariatinskii means not barristers, but the spokesmen for various political groups, in particular the so called représentants. Geneva had a vigorous legislative and debating culture. The "right of representation" (curtailed in 1782 and reintroduced in 1791) allowed citizens and bourgeois to apply to the Petit Conseil for the adoption of a regulation or to protest actions by the magistrates. According to William Coxe, "ces représentations sont peut-être un des meilleurs moyens qu'on ait employés pour mettre les privilèges du peuple à l'abri de l'usurpation respective des deux conseils," [W]illiam Coxe, Voyage en Suisse, t. 2 (P., 1790), 356. On Geneva's legislative culture of the time, see Christian Alain Müller, who writes that "un légalisme sourcilleux est largement partagé parmi les Genevois." Christian Alain Müller, "Nostalgie, révolution et régime républicain à Genève à la fin de l'Ancien Régime (1782-1792)," in Giovanni Bardazzi et Alain Grosrichard, eds., Dénouement des Lumières et invention romantique (Geneva: Droz, 2003), 19-46, here 27. By denigrating public debate, Bariatinskii reveals his misunderstanding of its centrality to Geneva's political system.

7. That the pursuit of self-interest was prevalent in the city is an impression echoed by other visitors. In his account written in 1793-1794, the Saxon traveller Christian-August Fischer wrote, "However those who will seek German cordiality and friendship in these societies will be disappointed ... The Genevans approach everything as Genevans, their egoism locks them in themselves. Things are important to them only by the advantage they can provide now or in the future, and they see all other members of the circles only as people who can benefit them." ChristianAugust Fischer, Über Genf und den Genfersee (Berlin 1796), 134-35 (my translation, A.S.).

8. In the context of Geneva, aristocracy refers to a group of families, drawn from the estate of the Citoyens, whose members sat in the Petit Conseil and the Conseil des Deux-Cents and therefore controlled all the official positions in the city. Since historically, these two councils co-opted their members and appointed all the magistrates, they served as the breeding ground of an elite that separated itself from fellow citizens and bourgeois. See Müller, "Nostalgie, révolution et régime républicain à Genève...," 26.

9. Bariatinskii refers to the Haute Ville, residence of the upper classes and seat of the organs of state, the Rues Basses (including Rive), a commercial and more popular neighbourhood and the abode of the rebellious circle of the Grille, and, on the other side of the Rhone river, the industrial and popular St Gervais, with several circles of natifs, who were less strategically placed for an assault on the seat of government, the Hôtel de ville. In the words of a contemporary: “Ceux qui connoissent la Ville de Genève savent qu'elle est divisée en Ville haute et Ville basse ; que le haut de la Ville est plus particulièrement habité par les Négatifs \& le bas par les Représentans ; d'où sont venues les dénominations de gens du haut et de gens du bas." [Jacques Antoine du Roveray], Le pour et le contre, ou éclaircissemens sur ce qui s'est passé à Genève, en février $1781 \ldots$ (Genève, 1781). (I am indebeted to one of my anonymous peer reviewers for this quotation, along with several other references.)

10. While the Petit Conseil combined legislative, judicial, and executive powers, its legislative proposals and its appointments had to be approved by the Conseil Général, composed of all the male bourgeois and citoyens (approx. 1,800 men out of a population of 35,000). However, 
Les beaux Arts languissent à Genève ${ }^{11}$. On n'y possède que l'art de s'enrichir; c'est qu'on a le bon esprit de préférer l'utile à l'agréable. [Il n'y a point de têtes exaltées, il n'y a que des têtes chaudes à Genève!...]

Le Genevois est économe autant par inclination que par nécessité. Il n'économise pas pour vivre mais il vit pour économiser. Il est assez dévot, mais il veut être libre de l'être ${ }^{12}$. Les ministres de Genève servent Dieu et le monde par semestre. Ce sont les comédiens de la religion chrétienne. On compte ceux qui croyent en la divinité de Jésus Christ, ou plutôt il n'y en a qu'un seul qui ne soit pas socinien ${ }^{13}$.

Ce serait un reproche injuste, que de refuser aux Genevois un caractère national. Mais cela ne prouve rien pour eux!... Les Juifs en ont un aussi.

La mendicité, ce redoutable ennemi des nations et des loix, n'est point connue à Genève. C'est une des causes du maintien des bonnes mœurs. « Tout se tient dans l'ordre moral! » ${ }^{14}[4]$

Genève se soutient par sa prodigieuse industrie. Ses fabriques sont les artisans de sa fortune. L'activité est son principe vital. Ses resources territoriales sont réduites à rien. La population de Genève est d'environ 28 à 30 mille âmes, en y comprenant celle du territoire. Elle peut être rangée sous deux classes générales. 1. Ceux qui n'ont part qu'aux droits civils, mais non aux droits politiques et à la souveraineté.

the Conseil Général could not propose or write its own laws; it could only vote up or down recommendations that emanated from the smaller councils. Nevertheless, the fact that contrary to other Swiss cities, Geneva had preserved this body ensured the maintenance of a republican check on aristocratic power. The fractured history of the city stemmed largely from its composite political system, which gave rise to the term of aristo-democracy as early as 1627 (Müller, "Nostalgie, révolution et régime républicain à Genève...,"29-33).

11. This received opinion-perhaps encouraged by Geneva's sumptuary laws, which, however, were rarely enforced - has been qualified by Danielle Buyssens in her La question de l'art à Genève du cosmopolitisme des Lumières au romantisme des nationalités (Genève: La Baconnière/Arts, 2008).

12. It was a commonplace to consider Geneva as a model of religious tolerance, even though citizens were obliged to profess Protestantism. And forbearance did not extend to renunciations of revealed religion, as we see in Rousseau's case. Coxe, for example, noted that "La république de Genève est, cependant à présent, la plus tolérante de tous les états réformés de Suisse; puisque c'est le seul gouvernement qui permette l'exercice public de la religion Luthérienne." Coxe, Voyage en Suisse, t. 2, 337.

13. Here Bariatinskii hyperbolizes the views of d'Alembert, who had stated in the Encyclopédie that "plusieurs ne croyent plus la divinité de Jesus-Christ" and "n'ont d'autre religion qu'un socinianisme parfait, rejettant tout ce qu'on appelle mysteres, \& s'imaginant que le premier principe d'une religion véritable, est de ne rien proposer à croire qui heurte la raison" (Encyclopédie, vol. 7, 578). This characterization, which was aimed primarily at Jacob Vernet, the prominent mid-century Genevan theologian, prompted an extensive rebuttal by Vernet himself. See David Sorkin, The Religious Enlightenment: Protestants, Jews, and Catholics from London to Vienna (Princeton: Princeton University Press, 2008), 82-85, 99-102. Rousseau likewise defended Genevan pastors in his Lettre à M. d'Alembert sur son article Genève (1758), although he subsequently fell out with Vernet, who was instrumental in the condemnation of the Social Contract and Emile.

14. This is a quotation from Jacques Necker, De l'importance de la morale et des opinions religieuses (London, 1788), 267. It comes from a passage in which the author calls for prudence and respect in the attack against religious feelings. 
2. ceux qui jouissent non seulement des droits civils, mais encore des droits politiques et participent à la souveraineté. Sous la 1-ère classe on comprend :

1 Les simples Habitants de la ville qui ont acquis à prix d'argent une espèce de lettre de naturalisation, laquelle leur donne le droit d'habiter dans la ville [4ob] et le territoire et d'y exercer leur industrie.

$2^{\mathrm{e}}$ leurs enfants nés dans la ville ou le territoire, lesquels sont appelés Natifs, et comme tels jouissent de droits civils plus étendus, dont le plus important consiste dans l'admission de droit à la Bourgeoisie, en outre les droits ordinaires de la Chancellerie, de la Bibliothèque et de l'Arsenal. ${ }^{15}$

La $2^{\mathrm{e}}$ classe comprend :

1 les Bourgeois, c'est-à-dire ceux qui ont acquis le droit de Bourgeoisie, et qui indépendamment de tous les droits civils peuvent entrer dans le Conseil des Deux-Cents et dans le Conseil Général, mais non parvenir aux magistratures.

2 les Citoyens. Ce sont les enfants des Bourgeois, nés dans la ville ou le territoire. Ils ont les mêmes droits et de plus qu'eux celui de pouvoir seuls être élus pour les magistratures. [5]

Les chefs de la République sont au nombre de quatre : on les appelle Syndics. Ils sont élus annuellement par le Conseil Général et tirés du Petit Conseil. Le Petit Conseil est composé de 25 citoyens tirés du Conseil des Deux-Cents. Il réunit le pouvoir judiciaire au pouvoir exécutif. Le Conseil des Deux-Cents dispose de la République entière au moyen de la part qu'il a usurpée dans les élections, de l'influence qu'il exerce sur le corps exécutif et judiciaire, dont il peut destituer à son gré tous les membres sans en rendre compte à personne qu'à sa conscience (c'est à dire à personne $)^{16}$, mais surtout par la faculté qu'il s'est attribuée d'empêcher toute nouvelle loi, toute interprétation de loi, tout redressement d'abus ou de violation des loix, d'être portés au Conseil Souverain. Il se recrute lui-même, [5ob] de concert avec le Petit Conseil, il est entièrement inamovible et indépendant de tout autre Corps. Il y a un siècle que tous les syndics n'étoient pas tirés de la caste aristocratique. Une moitié étoit du bas et l'autre étoit du haut ${ }^{17}$. Aujourd'hui c'est la fleur de l'aristocratie de Genève qui gouverne le vaisseau de l'Etat. [Voilà ce

15. Bariatinskii glosses over a contentious issue. Facilitated admission of the Natifs to the Bourgeoisie, until then severely restricted, was one of their core demands, and it was implemented only in the Projet d'édit of March 1791 and confirmed in the Code genevois of November 1791. Even then it was assorted with certain conditions, notably the payment of 300 florins.

16. It is unclear where Bariatinskii derives this information from, which is not entirely correct. It may refer to the grabeau, introduced in the Traité de pacification of 1782, whereby the Conseil des Deux-Cents and the Petit Conseil undertake a yearly revision of each other's members, with the right to exclude members, albeit without prejudice. See Title IX, articles 2-3, of the Traité de pacification (Geneva, 1782), 43-46. Coxe described this reform as a profound shift of balance that gave the Conseil des Deux-Cents some of the prerogatives of the General Council and made it into the centre of the aristocracy (Coxe, Voyage en Suisse, t. 2, 393).

17. This practice was in fact abolished in 1602, primarily for the sake of expediency, owing to the difficulty of finding suitable candidates. See Jean-Antoine Gautier, Histoire de Genève des origines à 1'année 1691, vol. 6 (Geneva: Société Générale d'Imprimerie, 1903), 451-452. 
gouvernement, si favorable à l'aristocratie, et si peu propre à assurer le bonheur d'une République.]

L'histoire de Genève est un apologue pour les peuples libres ou qui aspirent à l'être. Cette ville [dit un auteur ingénieux,] est une ruche sous verre, où l'on peut étudier toutes les ruses des frêlons aristocrates et toute l'industrie des abeilles ${ }^{18}$.

Genève ne sera jamais tranquille et bien moins encore libre. Cette assertion se prouve aisément. Qu'on ouvre le livre des révolutions de Genève, et l'on verra la cause première de toutes les guerres civiles qui ont ensanglanté cette terre de liberté. Ce sont les premiers efforts d'une [6] aristocratie naissante qui ont arraché du sein de la République cette douce tranquilité qui faisait jadis le charme des paisibles et heureux Genevois ; ce sont les progrès de cette même aristocratie qui ont fomenté des troubles toujours renaissants ${ }^{19}$. Ce sont enfin les derniers efforts d'une faction expirante qui ont nourri la haine et le désir de la vengeance dans le coeur des vrais patriotes, et qui par un concours de circonstances funestes ont mis Genève [il y a moins d'un an le 14 février en 91] au bord de l'abyme où quelques brigands étrangers voulurent le précipiter ${ }^{20}$. L'oligarchie [l'aristocratie] est une lime sourde qui use lentement et qui parvient à sa fin. [Dès que la machine est ébranlée, on voit chaque jour se détacher une partie de l'édifice.]

18. Bariatinskii is quoting a letter published in Camille Desmoulins's Révolutions de France et de Brabant, vol. 1 (1790), no 4, p. 175, although he omits the adjectives inutile and diligente in "C'est une ruche sous verre où l'on peut étudier toutes les ruses des Frêlons Aristocrates, et l'inutile industrie de la diligente abeille" (175). Given Desmoulins's enthusiastic support for the National Assembly and the way his "hypercritical journal" reflected on revolutionary tremors across Europe, the fact that Bariatinskii read the Revolutions de France et de Brabant is in itself significant. The letter from which this quotation is taken contains an indictment of the Genevan aristocracy as a class that usurped political rights. This analysis could have been one of the sources of Bariatinskii's views on the Genevan aristocracy: "vous savez qu'en 1782, nos Aristocrates ont envahi tous les pouvoirs. Ces Aristocrates n'étoient pas comme les vôtres, Ducs \& Pairs, Prélats, Marquis \& Haut-Barons, mais bien simples Bourgeois qui devenus un peu plus aisés que leurs compagnons se sont indignés de l'égalité politique établie par la loi, bien plus coupables, puisqu'ils n'avoient point sucé l'aristocratie avec le lait, dans de vieux Châteaux flanqués de tours. Ils ont voulu maintenir par les armes l'influence qu'ils s'étoient données dans le gouvernement, et se sont cloués dans le grand et petit Conseils. Pour y réussir, ils liguèrent contre nos libertés, la France, le Piémont et Berne, ... (174-175). He also adds, "Nos Aristocrates sont grands calculateurs" (179).

19. Since 1782 , moderate bourgeois insurgents framed their aspirations as a nostalgic restoration of a somewhat mythical vision of democratic rights usurped by the authorities. See Müller, "Nostalgie, révolution et régime républicain à Genève...," 22, 27-29.

20. There is a footnote in the original version of 1791: "Le 14 février en 1791 - quarante sans culottes du païs de Gex, quelques gardes nationales et tous les paisans de la banlieue, avec Dumont leur chef secret avaient formé le projet de s'emparer de Genève, pour en faire hommage à l'Assemblée Nationale!..." Bariatinskii describes the unrest among peasants, fomented in part by emissaries from Paris and by Jacques Grenus, then the militant mayor of a French village in the vicinity. However, tipped off about the French provocation and suspecting a plot to conquer the city, Genevans of all orders turned against the insurgents, who disbanded. Bariatinskii refers to Etienne Dumont, a bourgeois who had left Geneva for Paris in 1789, attempting to prevail upon French authorities to grant Geneva complete independence. He closely collaborated with Mirabeau in French affairs, while supporting the demands of the natifs through his writings. In early 1791 he returned temporarily to Geneva, but seems to have played a moderating role in the unrest of February 1791 (Golay, Quand le peuple devint roi, 242, n. 37). 
Ouvrez le Projet d'Edit de 1791. On y lit dans l'article V « Le Conseil exercera le pouvoir de la paix et de la guerre $»^{21}$. Cette phrase transporte hors de Genève... L'organisation [6ob] de la force publique occupe beaucoup les têtes genevoises ! Quinze cents horlogers sont les soutiens de la République. Leur général est un Syndic qui commande en cheveux longs, en manteau court et en habit noir. Genève n'est fortifié ni par l'art ni par la nature. Si l'on demandait à un Genevois pourquoi Genève n'a point de murailles, il vous répondrait comme Agésilaüs en montrant les soldats « Voilà les murailles de Lacédémone! » 22

21. Bariatinskii refers to the Projet d'édit, adopted on 22 March 1791. See https://doc.rero.ch/ record/11888. In Book 1, Article 2, Paragraph 5, one reads that "Le Conseil Souverain exercera... le pouvoir de la guerre et de la paix." This wording was then confirmed in the Code genevois adopted on 14 November 1791. The fact that Bariatinskii references the Projet, rather than the Code, may suggest that he wrote his text before 14 November 1791 . This clause, which also subjects the introduction of foreign troops to the Council's approval, is important as Geneva's independence was precarious, even though formally guaranteed by France and the cantons of Bern and Zurich. Foreign troops had intervened at critical junctures, notably by restoring the ruling oligarchy to power in 1782 . It is also significant that the Projet starts by defining the sovereignty of the General Council, on the one hand placing it at the heart of the Republic, but also limiting its power by determining its competencies. The point Bariatinskii seems to be making in this paragraph is that Geneva ought to count only on itself, i.e. on the sovereignty of its General Council, to safeguard its independence.

22. Geneva was, in fact, a fortified city and the government's policy of extending its fortifications became a political issue, pitting the ruling oligarchy against the bourgeoisie, which suspected the government of wasteful self-entrenchment. See Helena Rosenblatt, Rousseau and Geneva: From the First Discourse to the Social Contract, 1749-1762 (Cambridge: Cambridge University Press, 1997), 154. Arguments were made that fortifications were useless, even dangerous, if the city could not muster sufficient troops to man them, which it could not. See Matthieu de la Corbière et al., (eds), Les Monuments d'art et d'histoire du canton de Genève, vol. 3, Genève, ville forte (Bern: Société d'histoire de l'art en Suisse SHAS, 2010), 244-249. It is difficult to make sense of Bariatinskii's remark here, except perhaps as a dismissive quip about the government's policy. 